SAINS TANAH - Journal of Soil Science and Agroclimatology

Journal homepage: http://jurnal.uns.ac.id/tanah

\title{
Soil properties and shallot yield responses to different salinity levels
}

\author{
Jauhari Syamsiah $^{1 *}$, Rahayu Rahayu ${ }^{1}$, Wily Binafsihi ${ }^{2}$ \\ ${ }^{1}$ Department of Soil Science, Faculty of Agriculture, Sebelas Maret University, Surakarta, Central Java, Indonesia \\ ${ }^{2}$ Undergraduate Program of Soil Science, Faculty of Agriculture, Sebelas Maret University, Surakarta, Central Java, Indonesia
}

\begin{tabular}{|c|c|}
\hline ARTICLE INFO & ABSTRACT \\
\hline Keywords: & Successful management of saline water could have significant potential for agricultural \\
\hline Irrigation Water Salinity & development in many areas, particularly in freshwater-scarce regions. To date, the effect of \\
\hline Local Varieties & salinity on shallot (Allium Cepa L.) yield and growth parameters has not been studied in \\
\hline Soil Chemical Properties & detail specifically for local varieties cultivated in Inceptisols. Therefore, the present study \\
\hline Yield of Shallot & $\begin{array}{l}\text { was designed to evaluate the effects of different levels of irrigation-water salinity }(0,1,2 \text {, } \\
\left.\text { and } 3 \mathrm{dS} \mathrm{m}^{-1}\right) \text { on soil chemical properties, the growth, and yield of local shallot varieties. }\end{array}$ \\
\hline Article history & The experiment was conducted in pots using a randomized plot design with two factors and \\
\hline Submitted: 2020-05-10 & three replications. The results showed that increases in salinity level affected increases soil \\
\hline Accepted: 2020-06-16 & $\begin{array}{l}\mathrm{pH} \text {, exchangeable } \mathrm{Na} \text { percentages, and plant height growth. Nevertheless, bulb number } \\
\text { and weight, soil exchangeable } \mathrm{Ca} \text { and } \mathrm{Mg} \text {, soil organic carbon, and sodium adsorption ratio }\end{array}$ \\
\hline * Corresponding Author & (SAR) was not significantly affected. The findings of the present study suggest that the local \\
\hline $\begin{array}{l}\text { Email address: } \\
\text { ninukts@staff.uns.ac.id }\end{array}$ & $\begin{array}{l}\text { varieties-Brebes and Purbalingga-with irrigated salinity levels up to } 3 \mathrm{dS}^{-1} \text { can be } \\
\text { tolerated for shallot cultivation in Inceptisols. }\end{array}$ \\
\hline
\end{tabular}

How to Cite: Syamsiah, J., Rahayu, and Binafsihi, W. (2020). Soil properties and shallot yield responses to different salinity levels. Sains Tanah Journal of Soil Science and Agroclimatology, 17(1): $30-34$ (doi: 10.20961/stjssa.v17i1.41566)

\section{Introduction}

Crop yields and agricultural productivity are influenced by irrigation practices, especially water salinity levels (Li et al., 2019). Allocating freshwater to consumption by humans and livestock leaves limited resources for agricultural irrigation (Wu et al., 2016; Flörke, Schneider, \& McDonald, 2018). Therefore, to increase crop yields, it is necessary to seek irrigation alternatives to freshwater. Saline water has long been used in Indonesia especially in agricultural applications (Jalali, Kapourchal, \& Homaee, 2017), and its use poses a variety of challenges. Plants cultivated near the sea are subject to saline intrusion by seawater, and over time, the salinity level may induce salt accumulation in the root zone ( $\mathrm{Li}$ et al., 2019). The growth and yield reduction of crops in areas of the world prone to saline accumulation is a serious issue (Ashraf, 2009). This is especially true in Indonesia where, according to the Indonesia Statistical Agency (BPS), in 2014, 24,000 ha of shallot crops in Brebes Regency and 150 ha of shallot crops in Purbalingga Regency-both planted in Allium sp. and both located near the sea-experienced production failures caused by seawater intrusion (BPS, 2019).

Depending upon the plant species, salinity levels, and ionic composition of the salts decrease plant growth and yields (Rabie, Aboul-Nasr, \& Al-Humiany, 2005). Turhan, Kuscu, Özmen, and Demir (2014) examined the effect of different soil salinity levels $(1.60,2.87,4.14,5.41,6.68$, and $7.95 \mathrm{dS} \mathrm{m}^{-1}$ ) on garlic, and found that garlic can be grown satisfactorily with increased soil salinity up to $4.14 \mathrm{dS} \mathrm{m}^{-1}$, but the amount of total dry matter decreased considerably with increasing soil salinity above that point. Salt tolerance in plants is a complex phenomenon that involves morphological and developmental changes as well as physiological and biochemical processes. Previous studies have shown that the Allium species of shallot is a crop moderately sensitive to salt stress (Kadayifci, Tuylu, Ucar, \& Cakmak, 2005; Kiremit \& Arslan, 2016). Management of saline water for agricultural irrigation is a major challenge to efforts to enhance crop growth and yields. Therefore, this study examines the effects of salinity on Inceptisols chemical properties, and the growth and yield of two shallot cultivars under pot-growing conditions. 


\section{Materials and Method}

\subsection{Experiment design}

The experiment was conducted from June to September 2018-a period of 99 days after planting (DAP) - at the research station of Agriculture Faculty located in Karanganyar Regency, Indonesia. The average minimum/maximum temperatures and relative humidity were calculated at $28^{\circ} \mathrm{C} / 32^{\circ} \mathrm{C}$ and $65-90 \%$, respectively. The study was conducted using Brebes and Purbalingga cultivars, the most commonly gown shallot varieties in Indonesia. The cultivars have a stem length of approximately $25-44 \mathrm{~cm}$, and yields have been reported to range between $10 \mathrm{t} \mathrm{ha}^{-1}$ (Yuliani, 2017). Shallot seedlings were sown under polyethylene pots, three plants per pot, then filled with $15 \times 10^{3}$ g.pot ${ }^{-1}$ Inceptisols with a sandy/clay/loam texture consisting of sand (13.9\%), clay $(43.8 \%)$, and silt $(42.1 \%)$. Soil physical and chemical properties presented in Table 1. Following Sumarni, Rosliani, and Suwandi (2012), compost (71 $\mathrm{g} \mathrm{pot}^{-1}$ ) and phosphorus (2.1 $\mathrm{g} \mathrm{pot}^{-1}$ ) fertilizer were applied to the soil seven days before planting. Solid fertilizer $-1.78 \mathrm{~g}$ of urea, $1.27 \mathrm{~g}$ of $\left(\mathrm{NH}_{4}\right)_{2} \mathrm{SO}_{4}$, and $1.42 \mathrm{~g}$ of $\mathrm{KCL}$ per pot-was applied 30 days after planting. All irrigation was performed with tap water $\left(0 \mathrm{dS} \mathrm{m}^{-1}\right)$ as a control. Saline irrigation treatments were administered from planting through harvesting. Three levels of salinized water were produced by diluting salt with tap water $\left(0.64,1.28\right.$, and $1.92 \mathrm{~g} \mathrm{liter}^{-1}$ to equal 1,2 , and $3 \mathrm{dS} \mathrm{m}^{-1}$, respectively). The treatments included two cultivar varieties (Brebes and Purbalingga) and four levels of salinity (TO $=0 \mathrm{dS}$ $\mathrm{m}^{-1}, \mathrm{~T} 1=1 \mathrm{dS} \mathrm{m}^{-1}, \mathrm{~T} 2=2 \mathrm{dS} \mathrm{m} \mathrm{m}^{-1}$, and T3 $=3 \mathrm{dS} \mathrm{m}^{-1}$ ) with three replications in a completely randomized design.

\subsection{Soil chemical properties}

Soil $\mathrm{pH}$ was determined using a 1:2.5 soil to water solution ratio and a $\mathrm{pH}$ meter (Tetsopgang \& Fonyuy, 2019). Electrical conductivity was measured using a 1:5 soil to water solution ratio using an electroconductivity meter (Abd-Elwahed, 2019); soil organic matter was determined by the Walkey and Black method; and total nitrogen (N) was measured using the Kjeldahl method (Bremner, 1965). Soil total phosphorus (P) was measured using molybdenum antimony blue colorimetry after the $\mathrm{HClO}_{4}$ digestion of soil extracts (Murphy \& Riley, 1962). The exchangeable cations $\left(\mathrm{Ca}^{2+}\right.$ and $\left.\mathrm{Mg}^{2+}\right)$ were determined by Atomic Absorption Spectrophotometer (AAS) (David, 1960; Angassa et al., 2012). $\mathrm{Na}^{+}$was measured by flame-photometer, as was the determination of soil exchangeable calcium (Ca), magnesium ( $\mathrm{Mg}$ ), and sodium (Na) (Carson, 1980; Moyin-Jesu, 2007). Sodium Adsorption Ratio (SAR) was calculated using the following equation (Murtaza, Ghafoor, \& Qadir, 2006):

$\mathrm{SAR}=\mathrm{C}_{\mathrm{Na}} /\left[\left(\mathrm{C}_{\mathrm{Ca}}+\mathrm{C}_{\mathrm{Mg}}\right) / 2\right]^{1 / 2}$

where $\mathrm{C}_{\mathrm{Na}}, \mathrm{C}_{\mathrm{Ca}}$, and $\mathrm{C}_{\mathrm{Mg}}$ are the concentrations of the $\mathrm{Na}^{+}$, $\mathrm{Ca}^{2+}$, and $\mathrm{Mg}^{2+}$ in $\mathrm{mmol} \mathrm{L}^{-1}$.

\subsection{Crop measurement}

Seeds were initially harvested at 88 DAP and there were three subsequent harvests at three to four days intervals, depending on plant conditions and weather, until 99 DAP. Mini bulbs are tubers produced by shallots after the seeds are harvested. Measurements were made in vegetative and generative phases. Variables and time of observation were as follows: Observations were made at 63 DAP. The number of flower stalks that appeared with fully bloomed flowers on all plants in each treatment plot were counted. Shallot seed weights were determined by weighing the seeds produced in all kernels in each treatment plot.

Additional observations were made at harvest after seed processing was completed following the stages set forth by Istiqomah, Barunawati, Aini, and Widaryanto (2019), the harvested flowers were dried and separated from the stover, then seeds in the kernel were manually extracted and weighed. The harvested tubers were weighed as part of the shallot seed harvest, and tubers weight produced per plot, per treatment was recorded. Root dry weight and aboveground biomass dry weight were determined through destructive sampling and weighing the harvested fresh weight before being placed into the oven overnight at $60^{\circ} \mathrm{C}$ to derive dry weight for the measurement the following day.

\subsection{Statistical analysis}

The effects of irrigation-water salinity on soil chemical properties and shallot growth and yield were evaluated using the statistical software SPSS and were analyzed by two-way ANOVA followed by Duncan Multiple Range Test (DMRT) to determine statistically significant differences between means $(p \leq 0.05)$.

\section{Results}

\subsection{Soil chemical properties of saline soil}

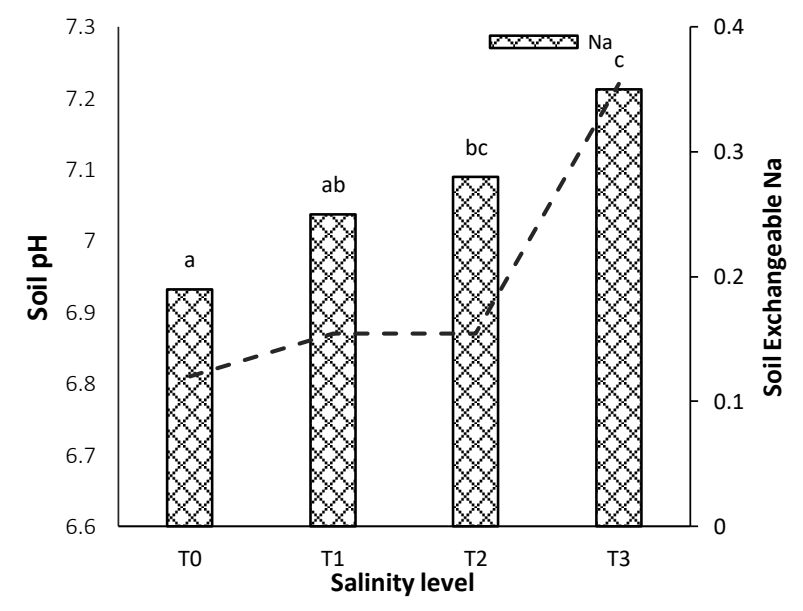

Figure 1. Soil $\mathrm{pH}$ and exchangeable $\mathrm{Na}$ as affected by different levels of salinity.

The results showed that the level of salinity affected soil chemical properties. The soil exchange of $\mathrm{Na}^{+}$increased with the increase of soil salinity; the exchange of $\mathrm{Na}^{+}$was greater at $\mathrm{T} 3>\mathrm{T} 2>\mathrm{T} 1>\mathrm{T} 0$. The treatments also revealed a significant difference in chemical properties; soil $\mathrm{pH}$ increased with the increase in salinity. At T0, $\mathrm{pH}$ was 6.81, at $\mathrm{T} 1$ and $\mathrm{T} 2, \mathrm{pH}$ increased to 6.87 , and at $\mathrm{T} 3, \mathrm{pH}$ rose to 7.22 (see Figure 1). The increase in $\mathrm{pH}$ is caused by $\mathrm{H}^{+}$ions released from the exchanger complex by the influence of other soluble cations in the applied saline water (Mahrous, Mikkelsen, \& Hafez, 1983; Akhwan, Sulistyaningsih, \& Widada, 2012). 


\subsection{Plant chemical properties, growth, and yield in} saline soil

Table 1. Soil chemical and physical properties at $30 \mathrm{~cm}$ soil depth

\begin{tabular}{|c|c|}
\hline Soil Properties & Values \\
\hline $\mathrm{EC}\left(\mathrm{dS} \mathrm{m^{-1 } )}\right.$ & 0.07 \\
\hline $\mathrm{pH}$ & $6-8$ \\
\hline $\mathrm{N}$ total (\%) & 0.18 \\
\hline Phosphorus availability $\left(\mathrm{mg} \mathrm{Kg}^{-1}\right)$ & 3.99 \\
\hline Exchangeable $\mathrm{Na}\left(\mathrm{me} 100 \mathrm{~g}^{-1}\right.$ ) & 0.66 \\
\hline Exchangeable $\mathrm{K}$ (me $100 \mathrm{~g}^{-1}$ ) & 0.17 \\
\hline Exchangeable $\mathrm{Mg}\left(\mathrm{me} 100 \mathrm{~g}^{-1}\right.$ ) & 1.05 \\
\hline Exchangeable Ca (me $100 \mathrm{~g}^{-1}$ ) & 8.03 \\
\hline C-Organic (\%) & 1.06 \\
\hline Sand (\%) & 13.97 \\
\hline Silt (\%) & 42.18 \\
\hline Clay (\%) & 43.85 \\
\hline Soil depth $(\mathrm{cm})$ & $30 \mathrm{~cm}$ \\
\hline
\end{tabular}

Table 2. Analysis of variance of the effects of salinity levels on soil properties.

\begin{tabular}{lc}
\hline \multicolumn{1}{c}{ Soil Properties } & Salinity \\
\hline $\mathrm{pH}$ & $0.05^{*}$ \\
Electrical conductivity & $0.88 \mathrm{~ns}$ \\
C-Organic & $0.69 \mathrm{~ns}$ \\
Exchangeable Na & $0.01^{*}$ \\
Exchangeable Ca & $0.06 \mathrm{~ns}$ \\
Exchangeable Mg & $0.11 \mathrm{~ns}$ \\
SAR & $0.25 \mathrm{~ns}$ \\
\hline
\end{tabular}

Note: $\mathrm{SAR}=$ sodium adsorption ratio; $\mathrm{ns}=$ are no significant; *and ${ }^{* *}=$ significant at $\mathrm{P}<0.05$ and ${ }^{*} * \mathrm{P}<0.01$

As shown in Figure 2, plant chemical properties were assessed as part of this study. The nutrient uptake by plants generally decreased with the increase of salinity levels. For example, $\mathrm{N}$ levels fell as follows: $2.67 \%, 2.53 \%, 2.51 \%$, and $2.23 \%$ for T0, T1, T2, and T3, respectively. Kalium levels ranged from: $2.16 \%, 1.70 \%, 1.66 \%$, and $1.59 \%$ for T0, T1, T2, and T3, respectively. The levels of $\mathrm{P}$ remained fairly stable, $0 \%$ at T0, and $0.01 \%$ at $\mathrm{T} 3$. Increases in salinity levels significantly affected the growth of shallots as demonstrated by the inverse relationship between salinity increases and inhibited plant heights: $33.37 \mathrm{~cm}, 32.13 \mathrm{~cm}, 27.68 \mathrm{~cm}$, and $27.57 \mathrm{~cm}$ for $\mathrm{T} 0, \mathrm{~T} 1, \mathrm{~T} 2$, and $\mathrm{T} 3$, respectively.

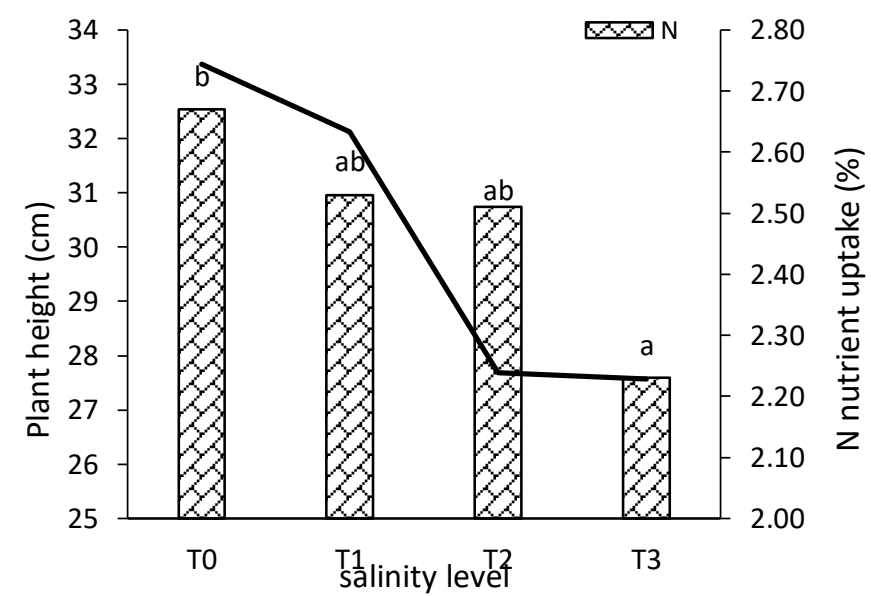

Figure 2. Plant height and N Nutrient uptake condition at the different levels of salinity

The yield parameters were not significantly affected by increases in soil salinity, but T1, with a salinity level of $1 \mathrm{dS} \mathrm{m}^{-1}$, had a higher number of bulb pieces (9-piece bulbs) and fresh and dry bulb weights (32.59 $\mathrm{g} \mathrm{pot}^{-1}$ and $26.67 \mathrm{~g} \mathrm{pot}^{-1}$ ) compared to T0, which had 7-piece bulbs, fresh and dry bulb weights of $32.43 \mathrm{~g} \mathrm{pot}^{-1}$, and $26.55 \mathrm{~g} \mathrm{pot}^{-1}$. In this study, a small increase in salinity level did not significantly affect biomass parameters such as fresh and dry of stem and bulb weights, respectively; however, increases in soil salinity beyond $\mathrm{T} 1$ caused a reduction in biomass from a high of 51.41 , $32.30,32.43$, and $26.55 \mathrm{~g} \mathrm{pot}^{-1}$ (TO) to a low 40.39, 25.95, 28.73 , and $24.27 \mathrm{~g} \mathrm{pot}^{-1}$ (T3).

Table 3. Effect of salinity level on plant parameters

\begin{tabular}{|c|c|c|c|c|c|c|}
\hline \multirow{2}{*}{ Analysis } & \multicolumn{6}{|c|}{ Treatments (dS $\mathrm{m}^{-1}$ ) } \\
\hline & $T_{0}(0.0)$ & $T_{1}(1.0)$ & $T_{2}(2.0)$ & $T_{3}(3.0)$ & Mean & F Test \\
\hline Plant height $(\mathrm{cm})$ & $33.37^{b}$ & $32.13^{b}$ & $27.68^{\mathrm{a}}$ & $27.57^{a}$ & 30.19 & $0.00 * *$ \\
\hline Stem fresh weight $\left(\mathrm{g} \mathrm{pot}^{-1}\right)$ & $51.41^{a}$ & $45.62^{a}$ & $35.26^{\mathrm{a}}$ & $40.39^{a}$ & 43.17 & $0.43 \mathrm{~ns}$ \\
\hline Stem dry weight $\left(\mathrm{g} \mathrm{pot}^{-1}\right.$ ) & $32.30^{\mathrm{a}}$ & $28.77^{a}$ & $24.53^{a}$ & $25.95^{\mathrm{a}}$ & 27.89 & $0.63 \mathrm{~ns}$ \\
\hline Number of bulbs & $7.17^{a}$ & $9.67^{a}$ & $7.33^{\mathrm{a}}$ & $5.83^{\mathrm{a}}$ & 7.50 & $0.45 \mathrm{~ns}$ \\
\hline Bulb fresh weight $\left(\mathrm{g} \mathrm{pot}^{-1}\right.$ ) & $32.43^{\mathrm{a}}$ & $32.59^{\mathrm{a}}$ & $22.19^{a}$ & $27.70^{\mathrm{a}}$ & 28.73 & $0.68 \mathrm{~ns}$ \\
\hline Bulb dry weight (g pot ${ }^{-1}$ ) & $26.55^{a}$ & $26.67^{a}$ & $19.60^{a}$ & $24.27^{a}$ & 24.27 & $0.65 \mathrm{~ns}$ \\
\hline $\mathrm{N}(\%)$ & $2.67^{b}$ & $2.53^{\mathrm{ab}}$ & $2.51^{\mathrm{ab}}$ & $2.23^{\mathrm{a}}$ & 2.67 & $0.08 \mathrm{~ns}$ \\
\hline $\mathrm{P}(\%)$ & $0.01^{\mathrm{a}}$ & $0.01^{a}$ & $0.00^{\mathrm{a}}$ & $0.01^{\mathrm{a}}$ & 0.01 & $0.24 \mathrm{~ns}$ \\
\hline $\mathrm{K}(\%)$ & $2.16^{\mathrm{b}}$ & $1.66^{a}$ & $1.59^{a}$ & $1.77^{\mathrm{ab}}$ & 1.79 & $0.04^{*}$ \\
\hline
\end{tabular}

Notes: The mean followed by the same letter indicates no significant difference in the same row $(P=0.05)$ by the DMRT test; ns= no significant; *and ${ }^{* *}=$ significant at $\mathrm{P}<0.05$ and ${ }^{*} \mathrm{P}<0.01$, respectively 


\section{Discussion}

The salinity levels of irrigation fluids influenced soil $\mathrm{pH}$ and exchangeable $\mathrm{Na}$ (Table 2); increasing salinity resulted in both soil $\mathrm{pH}$ and an increase in exchangeable $\mathrm{Na}$ (Figure 1). The higher soil $\mathrm{pH}$ is caused by the release of $\mathrm{H}^{+}$ions from the complex influence of other soluble cations in the saline soil (Mahrous et al., 1983; Akhwan et al., 2012); the higher $\mathrm{Na}^{+}$ concentration was created simply by the addition of greater quantities of saline $\left(0,1,2\right.$, and $\left.3 \mathrm{dS} \mathrm{m}^{-1}\right)$. Plant height and $\mathrm{Na}$ adsorption were the only growth parameters affected by the salinity level of irrigation waters (Table 3), it is suitable with a previous study that the toxic effect of $\mathrm{Na}$ inhibited plant growth (Adiku, Renger, Wessolek, Facklam, \& Hecht-Bucholtz, 2001). In addition, Yuliani (2017) observed that some varieties of shallot require ample $\mathrm{C}$-organic and exchangeable $\mathrm{Na}, \mathrm{Ca}$, and $\mathrm{Mg}$ for growth and yield production.

Also, soil pH is important; it governs the availability of nutrients (Zaki, Komariah, Rahmat, \& Pujiasmanto, 2018) and the import of fertilizer materials. For a majority of plants, the optimum pH for growth is between 6.5 and 7 (Gill et al., 2015).

This study showed that the level of salinity did not significantly affect growth and yield. Kiremit and Arslan (2016) reported similar findings: that varieties of Allium porrum L. can tolerate salinity in the field. According to Mangal, Lal, and Hooda (1989), onion bulbs and vegetative growth declined only when soil salinity values exceeded 4.0 $\mathrm{dS} \mathrm{m}^{-1}$. Previous studies have shown that salinity tolerance is a cultivar-dependent trait (Khaleghi, Karamnezhad, \& Moallemi, 2019), and there is a similar response between the gametophytic and sporophytic phases to abiotic stresses such as salinity (Koval, 2004; Ravikumar, Patil, \& Salimath, 2003; DeMicco, Scala, \& Aronne, 2006). A significant lack of any nutrient can cause a decrease in the growth and development of plants. Levels of plant $\mathrm{N}-$ a very important nutrient in plant growth (Brady \& Weil, 2002) decrease in response to increasing salinity conditions.

\section{Conclusion}

Irrigation water with high salinity levels leads to high soil $\mathrm{pH}$ and an increase in exchangeable $\mathrm{Na}$. The growth of shallot (Allium cepa L.) varieties Brebes and Purbalingga in this study was affected as reflected in decreased plant height; nitrogen as a significant growth factor, was inhibited and decreased at

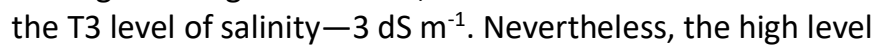
of salinity did not significantly affect yield components such as the number of bulbs, and fresh and dry bulb weight. This study shows that the growth and yield of local shallot varieties Brebes and Purbalingga are tolerant of salinity levels up to $3 \mathrm{dS} \mathrm{m}^{-1}$.

\section{Acknowledgments}

This research was supported by the Ministry of Research, Technology, and Higher Education of the Republic of Indonesia (KEMENRISTEKDIKTI). We would also like to show our gratitude to the dean of Agriculture Faculty, Universitas Sebelas Maret (UNS).

\section{Declaration of Competing Interest}

The authors declare no competing financial or personal interests that may appear and influence the work reported in this paper.

\section{References}

Abd-Elwahed, M. S. (2019). Effect of long-term wastewater irrigation on the quality of alluvial soil for agricultural sustainability. Annals of Agricultural Sciences, 64(2), 151-160. https://doi.org/10.1016/j.aoas.2019.10.003

Adiku, S. G. K., Renger, M., Wessolek, G., Facklam, M., \& Hecht-Bucholtz, C. (2001). Simulation of the dry matter production and seed yield of common beans under varying soil water and salinity conditions. Agricultural Water Management, 47(1), 55-68. https://doi.org/10.1016/S0378-3774(00)00094-9

Akhwan, I. A. S., Sulistyaningsih, E., \& Widada, J. (2012). Peran JMA dan bakteri penghasil ACC deaminase terhadap pertumbuhan dan hasil bawang merah pada cekaman salinitas. Vegetalika, 1(2), 53-70. https://doi.org/10.22146/veg.1528

Angassa, A., Sheleme, B., Oba, G., Treydte, A. C., Linstädter, A., \& Sauerborn, J. (2012). Savanna land use and its effect on soil characteristics in southern Ethiopia. Journal of Arid Environments, 81, 67-76. https://doi.org/10.1016/j.jaridenv.2012.01.006

Ashraf, M. (2009). Biotechnological approach of improving plant salt tolerance using antioxidants as markers. Biotechnology Advances, 27(1), 84-93. https://doi.org/10.1016/j.biotechadv.2008.09.003

BPS. (2019). Statistik hortikultura provinsi Jawa Tengah. Retrieved December 21, 2019, from www. distanbun.jatengprov.go.id

Brady, N. C., \& Weil, R. R. (2002). The nature and properties of soils (13th ed.). New Jersey, USA: Prentice- Hall Inc.

Bremner, J. M. (1965). Total nitrogen. In C. A. Black (Ed.), Methods of soil analysis. Part 2: Chemical and microbial properties (Number 9 i, pp. 1049-1178). Madison, USA: American Society of Agronomy Inc.

Carson, P. L. (1980). Recommended potassium test. In W. C. Dahnke (Ed.), Recommended Chemical Soil Test Procedures for the North Central Region, Bulletin 499 (pp. 17-18). Fargo, North Dakota, USA: North Dakota Agricultural Experiment Station.

David, D. J. (1960). The determination of exchangeable sodium, potassium, calcium, and magnesium in soils by atomic-absorption spectrophotometry. Analyst, 85, 495-503. https://doi.org/10.1039/AN9608500495

DeMicco, V., Scala, M., \& Aronne, G. (2006). Effects of simulated microgravity on male gametophyte of Prunus, Pyrus, and Brassica species. Protoplasma, 228, 121-126. https://doi.org/10.1007/s00709-006-0161-7

Flörke, M., Schneider, C., \& McDonald, R. I. (2018). Water competition between cities and agriculture driven by climate change and urban growth. Nature Sustainability, 1, 51-58. https://doi.org/10.1038/s41893-017-0006-8

Gill, R. A., Zang, L., Ali, B., Farooq, M. A., Cui, P., Yang, S., ... Zhou, W. (2015). Chromium-induced physio-chemical 
and ultrastructural changes in four cultivars of Brassica napus L. Chemosphere. Chemosphere, 120, 154-164. https://doi.org/10.1016/j.chemosphere.2014.06.029

Istiqomah, N., Barunawati, N., Aini, N., \& Widaryanto, E. (2019). True shallot seed production of lowland shallot under the application of seaweed extract and $\mathrm{N}$ fertilizer. Russian Journal of Agricultural and SocioEconomic Sciences, 6(90), 325-338. https://doi.org/10.18551/rjoas.2019-06.41

Jalali, V., Kapourchal, S. A., \& Homaee, M. (2017). Evaluating performance of macroscopic water uptake models at productive growth stages of durum wheat under saline conditions. Agricultural Water Management, 180, 1321. https://doi.org/10.1016/j.agwat.2016.10.015

Kadayifci, A., Tuylu, G. İ., Ucar, Y., \& Cakmak, B. (2005). Crop water use of onion (Allium cepa L.) in Turkey. Agricultural Water Management, 72(1), 59-68. https://doi.org/10.1016/j.agwat.2004.08.002

Khaleghi, E., Karamnezhad, F., \& Moallemi, N. (2019). Study of pollen morphology and salinity effect on the pollen grains of four olive (Olea europaea) cultivars. South African Journal of Botany, 127, 51-57. https://doi.org/10.1016/j.sajb.2019.08.031

Kiremit, M. S., \& Arslan, H. (2016). Effects of irrigation water salinity on drainage water salinity, evapotranspiration, and other leek (Allium porrum L.) plant parameters. Scientia Horticulturae, 201, 211-217. https://doi.org/10.1016/j.scienta.2016.02.001

Koval, V. S. (2004). Male and female gametophyte selection of barley for salt tolerance. Hereditas, 132(1), 1-5. https://doi.org/10.1111/j.1601-5223.2000.00001.x

Li, J., Gao, Y., Zhang, X., Tian, P., Li, J., \& Tian, Y. (2019). Comprehensive comparison of different saline water irrigation strategies for tomato production: Soil properties, plant growth, fruit yield, and fruit quality. Agricultural Water Management, 213, 521-533. https://doi.org/10.1016/j.agwat.2018.11.003

Mahrous, F. N., Mikkelsen, D. S., \& Hafez, A. A. (1983). Effect of soil salinity on the electro-chemical and chemical kinetics of some plant nutrients in submerged soils. Plant and Soil, 75, 455-172. https://doi.org/10.1007/BF02369980

Mangal, J. L., Lal, S., \& Hooda, P. S. (1989). Salt tolerance of the onion seed crop. Journal of Horticultural Science, 64(4), 475-477. https://doi.org/10.1080/14620316.1989.11515980

Moyin-Jesu, E. I. (2007). Use of plant residues for improving soil fertility, pod nutrients, root growth, and pod weight of okra (Abelmoschus esculentum L). Bioresource Technology, 98(11), 2057-2064. https://doi.org/10.1016/j.biortech.2006.03.007

Murphy, J., \& Riley, J. P. (1962). A modified single solution method for the determination of phosphate in natural waters. Analytica Chimica Acta, 27, 31-36. https://doi.org/10.1016/S0003-2670(00)88444-5

Murtaza, G., Ghafoor, A., \& Qadir, M. (2006). Irrigation and soil management strategies for using saline-sodic water in a cotton-wheat rotation. Agricultural Water Management, 81(1-2), 98-114. https://doi.org/10.1016/j.agwat.2005.03.003

Rabie, G. H., Aboul-Nasr, M. B., \& Al-Humiany, A. (2005). Increased Salinity Tolerance of Cowpea Plants by Dual Inoculation of an Arbuscular Mycorrhizal Fungus Glomus clarum and a Nitrogen-fixer Azospirillum brasilense. Microbiology, 33(1), 51-60. https://doi.org/10.4489/MYCO.2005.33.1.051

Ravikumar, R. L., Patil, B. S., \& Salimath, P. M. (2003). Drought tolerance in sorghum by pollen selection using osmotic stress. Euphytica, 133, 371-376. https://doi.org/10.1023/A:1025702709095

Sumarni, N., Rosliani, R., \& Suwandi. (2012). Optimasi jarak tanam dan dosis pupuk untuk produksi bawang merah dari benih umbi mini di dataran tinggi. Jurnal Hortikultura (ID), 22(2), 147-154. https://doi.org/10.21082/jhort.v22n2.2012.p148-155

Tetsopgang, S., \& Fonyuy, F. (2019). Enhancing growth quality and yield of cabbage (Brassica oleracea) while increasing soil $\mathrm{pH}$, chemicals, and organic carbon with the application of fines from volcanic pyroclastic materials on a tropical soil in Wum, Northwest Cameroon, Africa. Scientific African, 6, e00199. https://doi.org/10.1016/j.sciaf.2019.e00199

Turhan, M. S., Kuscu, H., Özmen, N., \& Demir, A. O. (2014). The effect of different salinity levels on the yield and some quality parameters of garlic (Allium sativum L.). Journal of Agricultural Sciences, 20, 280-287.

Wu, X., Zheng, Y., Wu, B., Tian, Y., Han, F., \& Zheng, C. (2016). Optimizing conjunctive use of surface water and groundwater for irrigation to address human-nature water conflicts: A surrogate modeling approach. Agricultural Water Management, 163, 380-392. https://doi.org/10.1016/j.agwat.2015.08.022

Yuliani, F. (2017). Respon Morfologi dan Fisiologi Tanaman Bawang Merah (Allium cepa L.) Terhadap Cekaman Salinitas. Institut Pertanian Bogor, Bogor, Indonesia. Retrieved from repository.ipb.ac.id/jspui/bitstream/123456789/87769 /1/2017fyu.pdf

Zaki, M. K., Komariah, Rahmat, A., \& Pujiasmanto, B. (2018). Organic amendment and fertilizer effect on soil chemical properties and yield of Maize (Zea mays L.) in rainfed condition. Walailak Journal of Science and Technology, 17(1), 11-17. 